\title{
Environmental Degradation and Sustainable Development in Nigeria: A Study of the South-South Region of Nigeria
}

\author{
Inyang, Bassey (Ph.D)* \\ Centre for General Studies, Cross River University of Technology, Calabar
}

*Corresponding Author: Inyang, Bassey, Centre for General Studies, Cross River University of Technology, Calabar

\begin{abstract}
Sustainable development and environmental degradation is an ongoing debate globally. This study is a contribution to the ongoing debate. Rapid exploration and exploitation of crude oil in the South-South region without effective environmental consciousness means that in virtually every area where there is oil exploitation, a substantial proportion of the population is at risk from natural and human induced environmental hazards. The study identifies that environmental degradation has devastating effect on individuals, society and economy at large and impacting negatively on the lives of the people and sustainable development as demonstrated of the damage, hardship and deaths caused by these hazards. The study also argues that the major cause of environmental degradation is a result of increased pressure on environmental resources by the population in various degrees that contributes to environmental unsustainability. The study concludes by recommending that national governments and non-governmental organisations should integrate environmental issues into decision making by elaborating new policies and strategies to tackle the hazards of environmental degradation for sustainable development.
\end{abstract}

Keywords: Environmental Degradation, Sustainable Development, Biodiversity, Ecosystem and Natural resources.

\section{INTRODUCTION}

For a long time, threats to human security were viewed in the realm of the manufacture, use and export of military weapons and the establishment of military bases in the world. But since the end of the Cold War, it would appear that there is some reduction in military pile-ups, though there are still threats to human existence through the use of light and small weapons. There seem to be a sharp decline since the early 1900 in civil wars and other forms of armed conflict as the number of refugees has also gone down and human rights abuses have decreased (Momah, 1999). Notwithstanding the above statement, the collective sense of insecurity is now higher than any other time before, because the forces that drive insecurity remain persistent and pervasive. Environmental degradation as a nonmilitary threat appears to be more deadly even now than the military threats. Other forms of environmental degradation include, soil pollution, climate change, desertification, flooding and erosion. These are the difficult situations facing human existence in the South-South region in particular and Nigeria in general.

The development of the South-South region and indeed the Nigerian economy has since the early 1980s taken a turn for the worst. In the 1980s, the Nigerian economy fell victim to a strain of what economist call "Dutch Disease", a precipitous decline following a windfall boom from exploiting natural resource brought on not by tulips but oil. It should be noted that in the oil producing communities in the South-South region, oil spills are frequent and the attendant problems are several and hazardous on the environment (Jimoh, 2006). Based on this, it could be said that land pressure and environmental pollution are responsible for declining food production in the South-South area. Under the circumstance, we observe that this situation of oil spillage and government insensitivity to the yearnings of the people has been engendering the phenomenon of soil pollution, water pollution and air pollution in the area. The consequences of these are that human beings, animals, and plants have been adversely affected.

Following the shift in thinking on what constitutes human security, one of the non-military threats of human security has been identified as environmental issues. Environmental security deals with 
environmental issues which threatens environmental security. However, while it is not the case that all environmental events can be said to be capable of threatening human security, such issues as climate change, deforestation and loss of biodiversity have been found to be capable of threatening human security. The United Nations has identified environmental degradation as one of six clustered threats with which the world must be concerned now and decades ahead (UNO, 2004:23).

Environmental degradation is the disintegration or the deterioration of the environment through the depletion of resources such as air, water and soil, the destruction of ecosystems, habitats destruction, the extinction of wildlife and pollution. When natural habitats are destroyed, or natural resources are depleted, the environment is degraded. Environmental degradation is also the deterioration in environmental quality from ambient concentrations of pollutants and other activities and processes such as improper land use and natural disaster. The United Nations International Strategy for Disaster Reduction (ISDR) defined environmental degradation as the reduction of the capacity of the environment to meet social and ecological objectives and needs (ISDR, 2004).

Agriculture both causes and suffers from environmental degradation. The International Soil Reference and Information Centre in the Netherlands estimates that, every year, 3 million hectares ( 7.4 million acres) of cropland are ruined by erosion, 4 million hectares are turned into deserts and 8 million hectares are converted to non-agricultural uses, such as homes, highways, shopping centres, factories and reservoirs. Over the past 50 years, some 1.9 billion ha of agricultural land (an area greater than that now in production) have been degraded to some extent. About 300 million hectares of this land are strongly degraded (meaning that the soil has deep gullies, severe nutrient depletion, or poor crop growth or that restoration is difficult and expensive). The causes of this extreme degradation vary: in Ethiopia, it is water erosion; in Somalia, it is wind; and in Nigeria, it is oil spillage, flooding and gully erosion (Binraban, 2012:4).

\subsection{Theoretical/Conceptual Framework}

The frustration-aggression theory is used to buttress this work. This theory is associated with the works of John Dollard et al., (1989), the core assumption being that "aggression is always a consequence of frustration". A good example of the way in which frustration leads to aggression can be seen in the ongoing crises in the Niger Delta area of Nigeria as a result of environmental degradation. By the late twentieth century, the need for structured environmental management became evident because of global pollution, loss of biodiversity, soil degradation and urban growth. In situations where feelings of frustration became widespread among the population and the feeling is that the people are getting less than they deserve, the most advisable that political leaders can do is to find out what the expectations of such individuals and groups are and to seek ways of negotiating with them and addressing the issues.

Secondly, definitions of environmental degradation are based on both biological productivity and the expectations about what the land should be like. Often, this is a subjective judgement, and it is difficult to distinguish between human caused deterioration and natural conditions, such as drought. We generally consider the land degraded when the soil is impoverished or eroded, water runs off or are contaminated more than normal and vegetation is diminished. On farmlands, this result in lower crop yields. On ranch lands, it means that fewer livestock can be supported per unit area. On nature reserves, it means lower biological diversity (Cunninghan: 2006: 160).

Environmental degradation is of two broad types: when natural habitats are destroyed or rendered unusable through pollution or contamination; or natural resources are misused, over-used, and made scarce and eventually depleted. Either of the two situations can result in deprivation of the populace of such critical essentials like food, water, quality air and basic survival resources. Where the situation degenerates into one of desperation by the people for any source of relief, it may result to human insecurity of the region and anyone who may interact with the region. This is the link between environment and human security (Otong, 2011).

As noted by Ambassador Jan Kubis, Secretary General of the Organisation for Security and Cooperation in Europe Research suggests that, though conflicts have multiple causes, the degradation, depletion or mismanagement of natural resources linked to demographic change can harm local and international stability in two ways: The first is by reinforcing and increasing grievance within and 
between societies: where few alternatives remain or where perceived inequities or opportunities for enrichments are great, groups may compete for resources, creating opportunities for violence. The second is by weakening states- by providing revenue for insurgents and criminal groups, depressing economic productivity, or undermining the legitimacy of the state in the eyes of the citizens (Kubis, 2006). Kubis position is that environmental degradation can cause people to lose faith in and become discontent with their leaders ability to govern them, promote development, provide basic goods and services and create a prosperous national economy. It is thus, of fundamental importance that policy makers have a clear view of the environment and security relationship, not only in the context of environmental issues that present immediate hazard to human security, but also those that are likely to affect the health of the planet and its inhabitants, particularly humans in the future. In terms of immediate hazard, reference can be made to such environmental problems as over-fishing, flood and erosion, deforestation, land/air/water pollution, hazardous waste, population growth, waste management, habitat and biodiversity preservation, pesticides and agricultural management among others (Kubis, 2006).

One of the first countries to make the clear connection between the environment and national security was the United States when in $1990 \mathrm{Mr}$ Al Gore, then a Senator placed environmental degradation on the national security agenda with his statement that environmental neglect threatens not only the quality of life but life itself. Environmental degradation did not come into the front burner as a major issue in Nigeria until 1988 following the dumping of toxic waste on a site in Koko, a small port town in the Southern part of Nigeria (Fagbohun, 2010). This led to the setting up of the Federal Environmental Protection Agency (FEPA) in 1988. By the time the Report of Vision 2010 Committee was published in 1997, it was acknowledged that Nigeria"es environment is facing many problems across the length and breadth of the country. These include population pressure and the continuous exploitation of marginal lands, aggravating the process of drought and desertification in the North; severe gully erosion in the Eastern and Northern States; coastal and marine erosion and land subsistence in coastal and riverine states; flooding in low-lying belt of mangrove and fresh water swamps along the coast, the plains of large rivers and short-lived flash floods in the inland rivers (Nigeria Vision 2010 Committee, 1997).

The threatening capacity of environmental degradation can be compared to both military and economic threats in its ability not only to affect the "national interest" of states, but the very interest of individuals and their communities. This is because ecological damage can damage the physical base of states to a sufficient extent to threaten their ideas and institutions (Busan, 1999). While it is an accepted fact that global warming represents a common crisis to the planet, nevertheless, states will continue to seek ways of asserting influence over others to ensure their advantage either militarily, economically, technologically or even culturally, even when such actions and policies lead to environmental degradation because states must cause something to happen in order to have something done. In essence, the pursuit of national interest of states represents a factor in exacerbating the dangers associated with environmental degradation on humanity.

Environmental crisis engender conditions which render conflict and insecurity all the more likely. They can serve to determine the source of conflict, shape the nature of conflict and act as multipliers that aggravate the core causes of conflict. Invariably, not only can an environmental problem contribute to conflict, they can also stimulate the growing use of force to repress disaffection among those who suffer the consequences of environmental degradation. The truce was broken in 1990 when the Movement for the Survival of the Ogoni People (MOSOP) and the Ijaw National Congress were founded. Their visions and strategies for political autonomy and socio-economic equity guided the emergence of other community grassroots (ethnic-based) social movements such as Ijaw Youth Movement (IYM) Ikwere Youth Movement and National Youth Council of Ogoni People among others. Ogoni exemplified the double layered contradictions being spawned by the further integration of the Niger Delta into the global capitalist system as a source of cheap oil. The murder of Ken SaroWiwa and eight Ogoni nationalists who were environmental and human rights activists, of the Movement for the Survival of Ogoni People (MOSOP) on Friday, November 10, 1995, by the military regime of General Sani Abacha, transformed the situation of peaceful protest into revolutionary pressures and militancy (Dara, 2010). 
The blood and echoes of the Ogoni Nine flowed till December 1998, when youths from 500 Ijaw communities met in Isaac Boro"s birth place of Kaima in Bayelsa State of Nigeria and issued the historic "Kaima Declaration". In October 1998, an oil pipeline fire killed about 1,000 persons in Jesse near Sapele in Delta State. The outrage generated by this environmental disaster united the nations of the Niger Delta against the Nigeria government and its multinational oil allies and cohorts (Dara, 2010). In November 1999, barely six months into the civilian regime of President Olusegun Obasanjo, soldiers invaded and destroyed Odi town in Bayelsa State under the pretext of searching for the killers of some police personnel (Dara, 2010). Where the environmental deficiencies are not tackled and curbed, they will degenerate in the not too distant future to undermine political, social and economic stability. The situation is worse where environmental resources form the core of a nation es earnings. Where such resource are wantonly depleted or mismanaged, the security of the nation will be undermined and there will be no sustainable development. Properly analysed, therefore, what the existentialist view does is to put environmental challenge under the national security label in recognition of the ultimate consequence of ignoring environmental problems (Fagbohun, 2010). The expectation in the circumstance is that since it is a national security interest, all threats to these interests (short, medium, or long term) will be addressed. This will not on itself take away the need to still identify within such national security strategy the appropriate level and form of remedy for the specific environmental problems. Consequently, whether focusing on environmental issues as national security concerns give the issues; feasibility is not what is important, rather, that the nation becomes more alert to the concerns and put in place effective solutions and strategies toward meeting the problems.

The moment one comes to term with a re-conceptualised nation of how we should think about national security, what becomes striking is that the "national security" label is not itself the end point, but a means to collate together anything that can be a threat to the stability and well-being of a nation, and ensure that there is in place a coordinated response to either mitigate or respond to it. It will not in itself take over the responsibility of the Ministry of Defence in relation to physical security or that of the Ministry of Environment in relation to environmental problems, or of the Ministry of Agriculture in relation to food security. What it should do is to guide the President to keep every threatening issue on the security alert radar, and interface all the relevant ministries, departments, parastatals and agencies of government that are supposed to work together on any particular issue to tackle the threat. In this way, the potential for militarisation of environmental policies or of a redefinition resulting in a threat to security will be minimal if not impossible as no agency or ministry will in playing its part compromise on its own duties or overreach on the activities of others.

\section{THREAT TO ENVIRONMENT}

Until the critical moment in Earthes history that is, the recognition of the danger associated with the degradation of the environment, the ecosystem- as a new threat to human security, other forms of threat dominate the discourse on conflict and security. Slavery, serfdom, military threats, war and colonialism had remained the main threats to humanity. For instance, for over 400 years, more than 15 million men, women and children, mostly from Africa, were the victims of the tragic slave trade, one of the darkest chapters in human history. Commemorated annually by the United Nations on March 25 every year, the occasion offers the opportunity to honour and remember those who suffered and died at the hands of the brutal slavery system.

Military threats are older forms of threat to peace and occupy the traditional heart of national security and peace. Military action can and usually does threaten all the components of the state. It subjects the physical base to strain, damage and dismemberment. It can result in the distortion or destruction of institutions, and it can repress, subvert or obliterate the idea of the state. Military actions not only strike at the very essence of the state ${ }^{\text {ee }}$ basic protective functions but also threaten damage deep down through the layers of social and individual interest which underlie and are more permanent than the state "es superstructures. Since, the state is more a social entity, an idea, than it is a physical being, the use of force threatens to overthrow a self-created rule by coercion. For all these reasons and also because the use of force can wreck major undesired changes very swiftly, military threats have normally been accorded the highest priority in national security concerns (Buzan 1983:75). 
By 1900, the world was home to about 1.6 billion people who used coal and firewood as sources of energy. In fact, the Industrial Revolution could not have taken place without the steam engine powered by coal. But the Industrial Revolution brought with it, not just progress in technology, science, medicine and modernity, it also introduced the degradation of the environment and its associated dangers to humanity. The use of coal as source of energy for the steam engine saw the emissions of smoke, smog, soot, and ash into the ecosystem, thereby fouling the air and introducing new forms of cardiac related diseases and illness. The Europeans who were responsible for the Industrial Revolution and the negative impact that such advancement, development and modernity brought, never saw it as endangering the world. Instead, they considered and treated these problems as if they were restricted to the local environment only. Because of that assumption, they found it easy to "escape" to other regions of the world which were virtually untouched by their activity (Kenedy, 1993).

Therefore, until the critical moment in earth "s history, these were some of the challenges to peace as well as sources of conflict that threatened humanity. But, the now-discovered impact of the degradation of the ecosystem was not only a credible and serious threat to peace; it also represented a source of conflicts for humanity and, indeed a potent global threat to all life on earth (Bakut, 2006).

\subsection{The Environment as a Threat to Peace}

Environmental degradation in the form of water pollution is essentially an economic problem more so that it is a bye-product of production and consumption activities. The resulting environmental ills pose extreme health hazards and loss of income for the growing numbers of people exposed to them. Such conditions are threat to human security and precipitate epidemics and natural health crises. In order for the government to meet the expanding needs of her citizens for sustainable development, environmental devastation through pollution of water must be halted.

Severe environmental degradation appears to be threatening the long-term development prospects of countries all over the world, particularly the developing countries such as Nigeria. This is so because they rely upon the use of natural resources being used up in manner that appears wasteful and thereby closes options for development in the future. According to Hishman (1993), the issue of the protection of the environment became a topical debate in Rio de Janeiro, Brazil in June 1992. The World Bank estimates that more than a million people in Sub-Saharan Africa still live in acute poverty and suffer gross inadequate access to resources required to give them opportunity for economic development. The immediate struggle for basic survival by the poor in various countries undermines the legitimate concerns of environmental protection and leads to subsequent pressure on the environment, with attendant pervasive degradations.

The concern for the environment was re-echoed at the World Earth Summit in Johannesburg, South Africa in August 2002. As part of the output of the Summit, a blue print tagged "The Johannesburg Plan of Action" was adopted. The document prescribes actions for tackling identified social, economic, political and environmental problems. The Action Plan contains among others, a commitment to half the proportion of people without access to safe drinking water and sanitation world-wide by the year 2015; the same year targeted by leaders at the United Nations Millennium Summit to reduce by half, the number of people living in poverty (Adenuga, 1999).

One important consensus in the literature to date is that, environmental problems-misuse of natural resources and pollution are rooted in the divergence between scarcity and price, benefits and costs, rights and responsibilities, as well as actions and consequences. And that the divergence exists because of a combination of market and policy failures that work together and/or independently to encourage a development type that is not sustainable. As soon as the environment assumes the character of scarce resources, it suggests that its deterioration constitute an economic problem. And so, the need to guard against likely threat arising from future scarcity of environmental resources following their over-exploitation and depletion, justifies the preservation of these resources. From the point of view of economics, scarcity of environmental resources will negatively affect three principal functions namely: resource supplier, life support system, and waste assimilation (Hueting, 1980).

Saro-Wiwa (1996) puts it this way, "The environment in oil producing communities has been completely devastated by three decades of reckless oil exploitation or ecological warfare by Shell. An 
ecological war is highly lethal, the more as it is unconventional. It is homicidal in effect. Human life, flora, fauna, the air, fall at its feet and finally, the land itself dies". This underscores the fact that the oil multinational contributes significantly to the environmental destruction of the South-South region of Nigeria.

Torulaga (2007) evaluated oil exploration and exploitation in the South-South region and pointed out that pipeline explosions take place during drilling activity by accidental bursting of pipeline while work is in progress. As a result of the consequences of oil explosions to lives, property and environment, people of the South-South have consistently blamed the oil companies and the federal government of Nigeria for showing nonchalant attitude and lacking any systematic mechanism to come to the aid of its citizens when emergency assistance is needed as a result of oil explosion. A case in point was the Jesse, Delta State pipeline explosion of October, 1998 in which over 1,000 people reportedly lost their lives.

There is much controversy surrounding the poverty and environmental degradation nexus. The predominant school of thought argues that poverty is a major cause of environmental degradation. The poor have traditionally taken the brunt of the blame for causing society ${ }^{\text {ee }}$ many problems. And so, the general consensus seems to be that poverty is the major cause of environmental degradation for example, in one of the conclusions of the Bruntland Commission Report, which incidentally has been accepted as the blue print for environmental conservation, it is explicitly stated that poverty is a major cause of environmental problems and amelioration of poverty is a necessary and central condition of any effective programme to deal with environmental concerns (Bruntland Commission, 1987).

Along similar lines, Jalal (1993) the Chief Executive of Asian Development Bank, of the Environment Department, argued that is in generally acceptable that environmental degradation, rapid population growth and stagnant production are closely linked with the fast spread of acute poverty in many countries in Asia. The World Bank (1992) joined the consensus with its World Development Report where it explicitly states, "poor families who have to meet short term needs mine the natural capital by excessive cutting of trees for firewood and failure to replace soil nutrients".

It is pertinent to state that the mismanagement of the environment in the South-South geopolitical zone of Nigeria has literally contributed to the problem of pollution, flooding, erosion and deforestation which has led to deterioration of the environs. According to Nwafor (2006), approximately 75 percent of gas produced is flared annually which has led to ecological and physical damages in our environment. Water, land, soil, vegetation and even the atmosphere are no longer conducive as a result of gas flaring. Nwafor further stated that environmental damage has also led to the loss of wildlife, pollution of air, loss of fertile soil, all of which has caused serious health problems in the lives of people affected. Environmental degradation constitute a threat to man es survival and to a large extent man has been responsible for this. Nwafor noted that there was no effort to check environmental degradation until 1972 "when the international community worked out a global sensitisation and management strategy in Stockholm" tagged the "magna carta" on which human environmental laws stands.

The South-South communities have remained grossly socio-economically underdeveloped and pauperised amidst the immense oil wealth owing to systematic disequilibrium in the production exchange relationship between the state, the transnational companies and the people. Enormous money had been derived from oil export but the area has been subjected to severe land degradation, socio-economic disorganisation, increasing poverty misery, military occupation and bloody violence (Peg, 1999).

This implies that oil extraction impacted most disastrously on the socio-physical environment of the South-South oil bearing communities massively threatening the fragile subsistent peasant economy and bio-diversity and hence their entire social livelihood and their very survival. The oil producing communities have basically remained dependent and underdeveloped, persistently alienated. The wealth derived from oil resource exploitation and exports benefit directly only the operators of oil industry and the bureaucrats in government. This is a serious threat to peace. 


\subsection{A Discourse on Sustainable Development and Environmental Degradation in the South- South Region of Nigeria}

"Sustainable development is development that meets the needs of the present, without compromising the ability of future generations to meet their own needs". The focus of sustainable development is far broader than just the environment. It is also about ensuring a strong, healthy and just society. This means meeting the diverse needs of all people in existing and future communities promoting personal wellbeing, social cohesion and inclusion, and creating equal opportunity (Bruntland, 1987:561).

Sustainable development contains within it two key concepts: namely the concept of needs, in particular the essential needs of the world ${ }^{\text {ees }}$ poor, to which overriding priority should be given and the idea of limitation imposed by the state of technology and social organisation on the environment $\mathrm{s}$ ability to meet present and future needs.

Sustainable development is maintaining a delicate balance between the human needs to improve lifestyles and feeling of well-being on one hand, and preserving natural resources and ecosystems, of which we and future generations depend. The term refers to achieving economic and social development in ways that do not exhaust a country"s natural resources (Ashford: 1995). Development may be thought of as the act of making purposeful changes to improve the quality of human life. However, environmental scientists have long pointed out that many forms of development have so degraded the natural environment that they threaten the very improvement for human lives that were intended (Brennan, 2005).

Torado (1981) in his book "Economic Development in the Third World", defines development as a process of improving the quality of all human lives. This includes raising people standard of living, creating condition conducive to the growth of people self-esteem and increasing people ${ }^{e e}$ s freedom to choose by enlarging the range of their choice variables. Development, if it is to be sustainable, should be environmentally safe, socially and economically equitable. Economic sustainability can be defined as that development strategy which takes into account not only increase in the Gross Domestic Product (GDP) or GDP per capita but also a conscious effort to minimise the harmful effects of economic activities on the natural resource base.

On the other hand, sustainable development refers to the basic of all people that must be met in a way which provides for their needs with security and dignity and without absolute limits to development. According to (Ekong, 2003), sustainable development means a conscious and deliberate effort aimed at helping communities recognise their capacities to participate fully in the life of the nation. By implication therefore, sustainable development involves active participation by the people themselves in effort to improve their level with as much reliance as possible on their own initiative and the provision of technical and other services in ways which encourage initiative, effective self-help and mutual help that meets the needs of the present without compromising the ability of future generations to meet their own needs (Stanley, 1995).

Sustainable development in the economic sense is one that does not reduce the productive base or the productive ability of the future generation as well. Therefore, it encourages the use of resources efficiently so as to ensure profitability and ethical management of ecology. The activities of oil exploration and exploitation in the South-South geopolitical zone of Nigeria, which led to adverse environmental degradation however, have gone contrary to the aforementioned assertion. Many of the multinational corporations operating in Nigeria today have been challenged of double standards. They have been accused of operating in Nigeria, with practice that would never be permitted in North America or Europe. As a result, there have been series of problems as: flooding and coastal erosion, sedimentation and siltation, degradation and depletion of water, light and noise pollution, air pollution, land subsistence, biodiversity depletion, as well as health problems and low agricultural production (HRW, 1999:52).

The violence in the south-south region is a reaction to a long history of exploitation, the presence of transnational corporations, a style of politics where violence is often encouraged and supported by politicians and the sheer welter of groups, gangs and cults without a leadership (Kashi, 2008). SouthSouth had grown into a hugely complex enigma with abysmal underdevelopment in the midst of plenty. Ibeanu (2003) captures it as the paradox of plenty, the paradox of national security and the 
paradox of development, while Amnesty International (2009:9) reports that the poverty of the SouthSouth, and its contrast with wealth generated by oil, has become one of the worldes starkest and most disturbing examples of the "resource curse". Paradoxically, the oil producing states have benefited least from the oil wealth. Devastated by the ecological costs of oil spillage and one of the highest flaring rates in the world, the South-South is a political tinderbox. As a result, the unemployed youths formed militia groups to seek redress against the government and the multinational corporations operating in the area. Sustainable development cannot be obtained in such region.

Crude oil production in the South-South region results in environmental degradation, destruction of rural livelihoods, aggravated poverty and reduced citizens to subjects (Amnesty international, 2009:7). The failure of the Nigerian state to respond meaningfully to the oil communities demands for full citizenship rights prepared the ground for the emergence of community grassroots (ethnic based) social movements wherein the youths constitute the crack troops to secure some form of political, cultural and economic autonomy.

As a result of environmental degradation caused by extensive oil extraction in the South-South region and the dredging of toxic waste into the rivers, the amount of fresh portable water decreased, the mangrove is damaged, and also damaged is the natural habitat such as fish, which is one the main sources of food for the people in the South-South region. The social environmental costs of oil production have been very extensive. They include destruction of wildlife and biodiversity, loss of fertile soil, pollution of air and drinking water, degradation of farmland and damage to aquatic ecosystems, all of which have caused serious health problems for the inhabitants of the area surrounding oil production. It is ironical that environmental regulations which are common practice in developed nations are often not followed due to government insensitivity to the yearnings of the people of the affected communities. As a result, oil companies often evacuate the inhabitants from their homelands to a new settlement, and thereby further marginalising them. No society can address the social, political and economic phenomenon of sustainable development in isolation of poverty and environmental degradation.

\section{CONCLUSION}

The impact of environmental disasters can be devastating on the social, economic and environmental systems of a country or region as well as the global ecosystem. To ensure sustainable utilisation of environmental resources calls for holistic approach in tackling the effect of environmental disasters. Therefore, governments, international organisations and communities, must work together at all levels to lessen the risks associated with environmental degradation. It is obvious that no society can address the social phenomenon of sustainable development in isolation of the problems of poverty and environmental degradation. Sustainable development means the usage of environmental resources by the present generation of human beings in such a way and manner that the future generation of the human race will come and meet such resources in better qualities and quantities than their predecessors.

Severe environmental degradation appears to be threatening the long-term development prospects of countries all over the world, particularly the developing countries such as Nigeria. This is because they rely upon the use of natural resources being used up in a manner that appears wasteful and, thereby, closes options for development in the future. There is also much controversy surrounding the poverty and environmental degradation nexus. The general consensus is that poverty is the major cause of environmental degradation. In a world where more than half of the population lives below poverty line, and where the consumption propensity of the wealthy few is on the increase, the problem of environmental degradation will continue to be on the increase.

Since development is about people, that is, present and future generations, the concern about sustainable development should take into account critical factors that influence its attainment. Therefore, there is a need to identify the parameters that will be used to set measurable threshold beyond which an environmental problem will contribute a threat to human security and warrant intervention. While it must be acknowledged that there are complexities in defining a threshold of threats, not to have any guide by governments and non-governmental organisations, will lead to distraction and create problems for effective intervention. Appropriate human security strategies must 
properly delineate how the relevant agencies will play their role to ensure that we do not have competing agencies and conflicting goals on environmental degradation issues.

There is also the need for a stricter enforcement of the existing environmental protection regulations, especially those pertaining to the production of hazardous wastes, Environmental Impact Assessment (EIA) and land use. Since development is about human beings, that is, the present and future generations, the concern of government about sustainable development should take into consideration the critical factors that influence its attainment.

\section{REFERENCES}

[1] Adenuga, A. O (1999) "Petroleum Industry and Environment Protection: The Nigerian Experience", Bullion Publication of the Central Bank of Nigeria. Volume 23, No.4, October/December.

[2] Amnesty International Report on the Niger Delta (2009). Nigeria: Petroleum, Pollution and Poverty in the Niger Delta June, 2009.

[3] Bakut, B. (2006), The Environment, Peace and Conflict in Africa In Introduction to Peace and Conflict Studies in West Africa, Best Shedrack Gaya. Ibadan: Spectrum Books Ltd.

[4] Berkowitz, L. (1962) Aggression: A Sociological Analysis. New York: McGraw Hill.

[5] Bindraban, P.S. (2012). ISRIC Study: Assessing the Impact of Soil Degradation of Food Production. Current Opinion in Environmental Sustainability, 2, 311-323.

[6] Bruntland Commission Report (1987) Our Common Future: The World Commission on Environment and Development. New York: Oxford University Press p56.

[7] Buzan, B. (1983). People, States and Fear. The National Security Problem in International Relations. New York: Harvester Wheat Sheaf.

[8] Buzan, B. (1999). People, States and Fear. ( $2^{\text {nd }}$ ed.) London: Harvester Wheat sheaf. P. 423.

[9] Cunningham, W.P (2006) Principles of Environmental Science: Inquiries and Applications. New York: McGraw Hill. p.534.

[10] Dara, G.G. (2010) Revolutionary Pressures in Niger Delta Literature. Journal of Contemporary Nigerian Writing, 1, 12-28.

[11] Ekong, E. (2003) An Introduction to Rural Sociology. Uyo: Dove Educational Publishers.

[12] Fagbohun, O. (2010). The Emergence and Development of Environmental Law in Nigeria. (1950-2010). In Azinge (ed) Law and Development in Nigeria: 50 Years of Nationhood. Lagos: Nigerian Institute of Advanced Legal Studies. Pp211.

[13] Heady, C. (2000) Natural resource sustainability and poverty reduction. Environment and Development Economies. 5,3. 241-258.

[14] Human Rights Watch (1999). The Price of Oil: Corporate Responsibility and Human Rights Violation in Nigeria"s Oil Producing Communities. Available at http/www.refworld.org/docid/3ae6a82eo.html.

[15] Ibeanu, O. (2003) "Spoils of Politics: Petroleum, Politics and the Illusion of Development in the Niger Delta Nigeria". ACAS Bulletin No. 64 2002/2003.

[16] Jalal, K.F. (1993) Sustainable Development, Environment and Poverty Nexus.Occasional Papers. No. 7 Manila: Asian Development Bank.

[17] Kashi, E. (2008) "Shadows and Light in the Niger Delta" in Michael Watts (ed) Curse of the Black Gold: 50 years, Lagos: Concept Publications Ltd.

[18] Kenedy, P. (1993), Preparing for the Twenty-first Century. $5^{\text {th }}$ edition. London: Fontona Press.

[19] Kubis, J. (2006) Initiatives for Change. Our Planet Magazine. Available at http/www/ourplanet.com/ text version.

[20] Momah, S. (1999).Global Disorders and the New World Order. Lagos: Vista Books, p. 208.

[21] Nigeria Vision 2010 Committee (1997).Report of the Vision 2010 Committee Main Report.

[22] Nwa for, J.C. (2006) Environmntal Impact Assessment for Sustainable Development: The Nigerian Perspective. Enugu: El Demak, p.432.

[23] Otong, E. U. (2011) Environmental Disaster Management Abuja: Kakapo Press, p.187.

[24] Pegg, S. (1999) "The Cost of Doing Business: Transnational Corporations and Violence in Nigeria". Turkey: Belkin University Press.

[25] Stanley, G.H. (1995) The Pursuit of Sustainability: Joining Science and Public Choice. The George Wright Forum $12(3)$. 
[26] Todaro, M.P. (1981) Economic Development in the Third World ( $2^{\text {nd }}$ ed.), London: Longman.

[27] United Nations Organisation (2004). A More Sure World. Our Shared Responsibility. Report of the Secretary-General ${ }^{\text {ee }}$ S High-level Panel on Threats, Challenges and Change. New York: United Nations Department of Public Information. p.1009.

[28] World Bank (1992). Development World Bank: Oxford University Press.

\section{AUTHOR'S BIOGRAPHY}

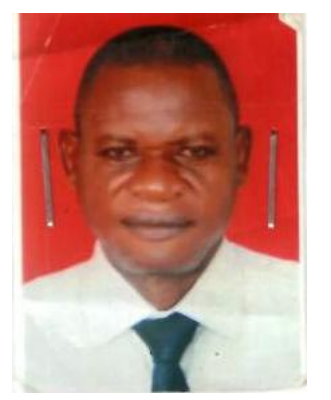

Inyang, Bassey, a Senior lecturer in the Centre for General Studies, Faculty of Communication Technology Cross River University of Technology, Calabar.

Citation: Inyang, Bassey. "Environmental Degradation and Sustainable Development in Nigeria: A Study of the South-South Region of Nigeria". International Journal of Humanities Social Sciences and Education (IJHSSE), vol. 6, no.8, 2019, pp. 33-42. doi: http://dx.doi.org/10.20431/2349-0381.0608004.

Copyright: (C) 2019 Authors. This is an open-access article distributed under the terms of the Creative Commons Attribution License, which permits unrestricted use, distribution, and reproduction in any medium, provided the original author and source are credited. 